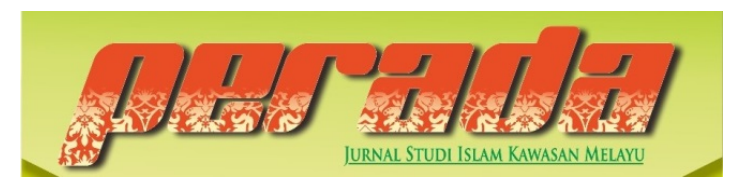

\author{
Perada: Jurnal Studi Islam Kawasan Melayu \\ ISSN 2656-7202 (P) ISSN 2655-6626 (E) \\ Volume 2 Nomor 2, Juni-Desember 2019 \\ DOI: $10.35961 /$ perada.v2i2.54
}

\title{
MODEL GRAMATIKA KOMUNIKATIF BIMBINGAN SKRIPSI MAHASISWA PROGRAM STUDI MANAJEMEN PENDIDIKAN ISLAM STAIN SULTAN ABDURRAHMAN KEPULAUAN RIAU
}

\author{
Eka Rihan $K$ \\ STAIN Sultan Abdurrahman Kepulauan Riau \\ ekarihank@yahoo.com \\ Satrio \\ STAIN Sultan Abdurrahman Kepulauan Riau \\ satrio@stainkepri.ac.id
}

\begin{abstract}
ABSTRAK
Model gramatika komunikatif merupakan salah satu model untuk melihat kompetensi bahasa yang menyangkut masalah komunikasi ditinjau dari komponen pragmatik, semantik dan sintaksis. Model gramatika komunikatif ini dipilih untuk mendeskripsikan proses bimbingan skripsi mahasiswa dilihat dari komponen pragmatik, semantik dan sintaksis. Metode penelitian deskriptif kualitatif. Pengumpulan data menggunakan teknik perekaman video atau audio ketika proses bimbingan skripsi berlangsung. Selain itu juga menggunakan pedoman observasi dan pedoman wawancara tidak terstruktur (interview guide) sedangkan analisis data menggunakan reduksi data, penyajian data dan penarikan kesimpulan/verifikasi. Konteks aktual mempunyai satuan alternatif. Beberapa diantaranya normal dan memenuhi postulat dasar proses-proses komunikasi Komponen Pragmatik Data 19 dan Data 31 terdapat tuturan konteks aktual menggunakan ciri ke sana dan dari sana menunjukkan tempat di mana kegiatan yang sama dari pembicara dan pendengar dilakukan. Beberapa tuturan dalam proses bimbingan skripsi antara mahasiswa dengan dosen pembimbing telah ditemukan ada yang sudah komunikatif dan ada yang belum komunikatif pada komponen pragmatik, komponen semantik dan komponen sintaksis. Beberapa tuturan kalimat perintah dan kalimat permintaan pada komponen sintaksis telah memenuhi aneka kalimat bahasa Indonesia dari sudut pandang komunikatifnya.
\end{abstract}

Kata kunci: komunikeasi, gramatik, pendidikan

Abstract: The communicative grammatical model is one of the models for viewing language competencies involving communication problems in terms of pragmatic, semantic and syntactic components. This communicative grammatical model was chosen to describe the process of student thesis guidance as to what can be communicative walking seen from the components of pragmatics, semantics and syntax. Qualitative descriptive research method. Data collection uses video or audio recording techniques when the thesis guidance process takes place. 
Besides that, it also uses observation guidelines and interview guide methods while data analysis uses data reduction, data presentation and conclusion / verification. The actual context has alternative units. Some of them are normal and fulfill the basic postulates of the Pragmatic Component communication process Data 19 and Data 31, there are actual context utterances using traits there and from there showing places where the same activities of the speaker and listener are performed. Some utterances in the thesis guidance process between students and supervisors have been found to have been communicative and some have not been communicative on pragmatic components, semantic components and syntactic components. Some command sentence utterances and request sentences on syntactic components have fulfilled various Indonesian sentences from the communicative point of view.

Keywords: communicative, grammar, education

\section{PENDAHULUAN}

Bahasa bukan saja representasi bentuk-bentuk hubungan yang logis antar unsur bahasa tetapi juga merupakan salah satu alat komunikasi yang maknanya dapat diketahui apabila kita melibatkan konteks bahasa atau konteks komunikasi yang ada pada saat seseorang mencoba memahami bahasa sehingga dari model komunikasi tersebut dapat diketahui bahwa ilmu tata bahasa berupa sintaksis, semantik dan pragmatik tidak mungkin terpisah satu dari lainnya. Sintaksis berkaitan dengan ilmu tata kalimat, semantik berkaitan dengan pemaknaan, dan pragmatik berkaitan dengan fungsi bahasa terkait konteks situasi tuturan. Ilmu tata bahasa tersebut apabila digabungkan akan tergambar pada ciri-ciri bahasa.

Ciri-ciri bahasa menurut Wardhaugh ${ }^{1}$ terbatas pada bahasa manusia, meliputi ciri-ciri (1) bahasa itu sistematis, (2) bahasa itu generatif, (3) bahasa itu kesatuan simbol yang arbitrar, (4) simbol-simbol tersebut bersifat vokal, (5) simbol tersebut mempunyai makna konvensional terhadap acuannya, (6) bahasa dipakai untuk komunikasi, (7) bahasa berlaku dalam komunitas atau budaya bahasa, (8) bahasa ada pada manusia, (9) bahasa diserap semua orang dengan cara yang sama - bahasa dan

${ }^{1}$ Ronald Wardhaugh, The Context of Language, (Rowley: Newbury House Publishers, Inc, 1976) h.7. pembelajaran bahasa mempunyai karakteristik yang universal. Unsur bentuk, makna dan fungsi terdapat kaitan satu dengan yang lain sesuai dengan konteks bahasa yang kita pakai saat kita berkomunikasi dengan bahasa. Gramatika berkaitan dengan tata bahasa. Menurut Yasin $^{2}$ sebuah gramatika yang utuh melingkupi aspek komunikatif dan aspek bahasa mempunyai empat komponen secara simultan meliputi komponen pragmatik, komponen semantik, komponen sintaksis dan komponen fonologi.

Menurut Yasin ${ }^{3}$ bahasa yang utuh tidak dapat diterangkan hanya dengan bentuk (seperti pada gramatika transformasi generatif) atau hanya dengan peran semantik (seperti pada gramatika kasus) atau hanya dengan pragmatik tanpa menghiraukan kaidah bahasa. Bahasa dapat diterangkan secara utuh bila ketiga aspek bahasa (sintaksis, semantik dan pragmatik) dikaji secara sejalan, seperti sebuah tuturan dapat diterangkan bentuknya karena ada makna dan fungsi atau konteksnya. Kompetensi bahasa telah disinggung panjang lebar dengan mengemukakan pendapat para ahli bahasa. Ternyata semakin dalam mereka menggali bahasa semakin disadari bahwa kompetensi tidak hanya menyangkut

${ }^{2}$ Anas Yasin, Tindak Tutur: Sebuah Model Gramatika Komunikatif, (Padang: Sukabina Offset, 2008), h.162.

${ }^{3}$ Ibid, h.161. 
masalah internal bahasa tapi juga kompetensi yang menyangkut masalah komunikasi, yaitu fungsi bahasa (tindak tutur) dan konteks bahasa.

Model gramatika komunikatif merupakan salah satu model untuk melihat kompetensi bahasa yang menyangkut masalah komunikasi ditinjau dari komponen pragmatik, semantik dan sintaksis. Model gramatika komunikatif ini dipilih untuk mendeskripsikan penelitian dasar pengembangan program studi yang berkaitan dengan proses bimbingan skripsi mahasiswa yang seperti apa dapat berjalan komunikatif dilihat dari komponen pragmatik, semantik dan sintaksis. Sebab tanpa bimbingan yang komunikatif dapat membuat mahasiswa jenuh dan tidak tertarik untuk melakukan bimbingan skripsi secara intensif. Berdasarkan uraian di atas maka peneliti tertarik untuk meneliti model gramatika komunikatif dengan fokus kajian meliputi tentang komponen pragmatic, sementik dan sintaksis terbentuk dalam proses bimbingan skripsi mahasiswa.

\section{MODEL GRAMATIKA KOMUNI- KATIF}

Bahasa bukan saja merupakan bentuk struktur tetapi juga fungsi yang harus disesuaikan dengan konteks dalam penggunaannya. Bentuk bahasa dapat diterangkan dengan menggunakan gramatika transformasi generatif sebagai titik tolak berfikir untuk masuk ke gramatika kasus dan pragmatik yang dijadikan dasar kajian dalam pembentukan model gramatika komunikatif. Transformasi generatif hanya melihat hubungan yang logis antarunsur dalam suatu kalimat tanpa mengkaji peran semantik masing-masing kategori dalam kalimat dan juga tidak mengkaji fungsi komunikasi bahasa sesuai dengan konteks penggunaannya.

Gramatika kasus telah diangkat dalam sauatu oposisi dan fungsi komunikasi bahasa sesuai dengan konteks dalam penggunaannya. Menurut Yasin ${ }^{4}$ sebuah gramatika yang utuh yaitu gramatika yang melingkup keduanya aspek komunikasi dan aspek bahasa, mempunyai empat komponen secara simultan. Komponen tersebut ialah (1) komponen pragmatik, (2) komponen semantik, (3) komponen sintaksis, dan (4) komponen fonologi. Masing-masing terdiri atas subkomponen seperti berikut:

A. Komponen Pragmatik

(1) Konteks

(a) Konteks Ekstralinguistik

(b) Konteks Linguistik

(2) Fungsi Tindak Tutur

B. Komponen Semantik

(1) Alat Komunikasi

(a) Unit unsur tindak ilokusioner

(b) Modalitas + Proposisi

C. Komponen Sintaksis

(1) Urutan tindak ilokusioner

(2) Urutan unsur modalitas + verba + Kasus

(3) Leksikon

D. Komponen Fonologi

Komponen model gramatika komunikatif yang digunakan dalam penelitian ini meliputi komponen pragmatik, komponen semantik, komponen sintaksis dan komponen fonologi. Moates mengemukakan bahwa dalam berbahasa atau proses komunikasi verbal, pertanyaan pertama tentang penutur ialah: Apa tujuan penutur? "Apakah ingin mengulas, membujuk, bertanya, menguraikan sesuatu, atau menyakiti?" Setiap tujuan mengarah kepada makna yang berbeda. Pertanyaan selanjutnya ialah bagaimana penutur mencapai tujuannya. Strategi penutur dalam mencapai tujuan tersebut harus didasarkan pada pengetahuannya, konteks percakapan, dan apa yang didengarnya tentang konteks percakapan, dan apa yang didengarnya tentang pendengar.

${ }^{4}$ Ibid. 
Tahapan-tahapan yang dilalui penutur dalam proses penuturan dan pemahaman menurut Moates ${ }^{5}$ adalah (1) memilih makna yang akan diungkapkan, (2) memilih struktur sintaksis, (3) meletakkan kata-kata pada struktur sintaksis, (4) menentukan bentuk-bentuk morfologis kata, (5) menentukan representasi fonemis untuk kalimat tersebut, (6) memilih perintah motoris, dan (7) mengucapkan tuturan. Apa yang dikemukakan Moates dapat ditarik garis besar tahapan dalam penuturan, yaitu: tahap pertama merupakan pemilihan makna, tahap kedua, ketiga dan keempat merupakan struktur sintaksis, tahap kelima pembentukan struktur fonemis, dan tahap keenam dan ketujuh proses motoris. Untuk mencapai tujuan, penutur mendasarkan strateginya pada konteks pertuturan, baik konteks situasional maupun konteks linguistik. Berikut ini uraian keempat komponen tersebut.

\section{A. Komponen Pragmatik}

Komponen pragmatik terdiri atas subkomponen konteks dan fungsi. Konteks adalah faktor luar (eksternal) yang menentukan fungsi komunikasi bahasa, sedangkan fungsi bahasa dapat dipilih hanya melalui konteks.

\section{Konteks}

Konteks dalam model gramatika komunikatif melibatkan pragmatik dan linguistik. Objek garapannya adalah tuturan (yang merupakan alat dalam komunikasi verbal) yang melibatkan dua partisipan atau lebih. Komunikasi dengan menggunakan bahasa, unit pikiran yang direpresentasikan dengan satu kasus dan verba (yang dapat dilengkapi dengan kasus-kasus lain dan unit tindak ilokusioner disebut tuturan, bukan kalimat.

${ }^{5}$ Danny R. Moates, dan Gary M. Schumacher, Cognitive Psychology, (Belmont: Wodsworth Publishing Company, 1980).
Perbedaan tuturan dengan kalimat ialah bahwa tuturan selalu mempunyai konteks yang yang mempengaruhi makna tuturan tersebut, baik konteks ekstralinguistik maupun konteks linguistik menurut Brown ${ }^{6}$, sedangkan kalimat mempunyai makna meta bahasa yang sama sekali terpisah dari komunikasi. Istilah "kalimat" telah digunakan dalam aliran gramatika tradisional, struktural dan transformasi, sedangkan tuturan dipakai dalam pragmatik, khususnya tindak verbal atau performansi yang terjadi pada situasi dan waktu tertentu. Dalam hal ini, pragmatik berkaitan dengan bahasa pada tingkat yang lebih kongkrit dibandingkan dengan hanya gramatika menurut Leech ${ }^{7}$.

Konteks terbagi atas konteks situasional (ekstralinguistik) dan konteks linguistik. Konteks situasional diperinci lagi menjadi konteks budaya dan konteks langsung. Konteks linguistik direalisasikan sebagai konteks wacana (karena objek kajiannya adalah kalimat dengan lingkungannya, wacana) dan konteks semotatik menurut Werth ${ }^{8}$.

\section{Konteks Budaya}

Kebudayaan suatu masyarakat bahasa ikut menentukan kepribadian, sikap dan tingkah laku masyarakat tersebut. Seterusnya kepribadian, sikap dan tingkah laku tersebut akan mempengaruhi cara berbahasa, dan karena itu juga menentukan pola bahasa yang mereka pakai.

Konteks Langsung

Konteks langsung ialah variabel sosiolonguistik yang mempunyai hubungan langsung dengan tuturan. Variabel tersebut ialah setting, partisipan, bentuk bahasa, topik, dan fungsi tindak

\footnotetext{
${ }^{6}$ Gillian Brown dan George Yule, Discourse Analysis. (London: Cambridge University Press, 1985).

${ }^{7}$ Geoffrey Leech, Principles of Pragmatics. (London: Longman Group, 1983). ${ }^{8}$ Paul Werth, Focus, Coherence, and Emphasis. (London: Croom Helm, 1984).
} 
tutur menurut Freedle?. Setting adalah tempat, waktu dan situasi di mana tuturan terjadi. Partisipan melibatkan penutur dan lawan tutur. Bentuk bahasa, seperti bahasa tulis dan bahasa lisan atau kode bahasa tertentu yang dipakai untuk mengungkapkan makna khusus, juga membedakan bentuk bahasa yang dipakai. Topik pembicaraan juga sangat berpengaruh terhadap bentuk bahasa yang dipakai, misalnya dalam percakapan politik, orang cenderung menggunakan bahasa yang berbentuk formal dengan urutan logika yang teratur. Tetapi percakapan tentang pengalaman lucu cenderung diungkapkan dengan menggunakan bentuk bahasa yang informal dan urutan pikiran yang melompat-lompat. Fungsi bahasa juga merupakan salah satu aspek yang mempengaruhi bentuk bahasa yang dipakai.

\section{Konteks Lingustik}

Terdapat dua macam konteks subbagian dari konteks linguistik ini, yaitu konteks wacana dan konteks semotaktik. Namun konteks wacana lebih banyak dibicarakan dalam konteks linguistik, sedangkan konteks semotaktik lebih banyak berkaitan dengan bidang sintaksis, misalnya penentuan makna berdasarkan unsur dalam suatu kategori atau proposisi dan tuturan. Konteks linguistik ialah pertanda-pertanda kebahasaan yang dapat memberikan petunjuk tentang hubungan pertanda tersebut dengan unsur-unsur atau aspek bahasa yang ada disekitarnya. Fungsi Tindak Tutur

Fungsi tindak tutur adalah fungsi komunikatif sebuah tuturan. Secara garis

${ }^{9}$ Roy Freedle, "Sociolinguistic Approach to Dialogue with Suggested Aplications to Cognitive Science", di dalam Roy Freedle (ed.), New Directions in Discourse Processesing, Vol. II, Advances in Discourse Processes. (Norwood: Ablex Publishing Corporation, 1979). besar, Halliday ${ }^{10}$ mengemukakan tiga fungsi bahasa, yaitu (1) fungsi ideasional, (2) fungsi interpersonal, (3) fungsi tekstual. Yang pertama mengacu pada apa yang biasa disebut makna kognitif, atau konten proposisi sebuah tuturan atau kalimat; yaitu kedua mengacu pada perlakuan pengungkapan tindak bahasa antara dua partisipan atau lebih (seperti pertanyaan, perintah, bujukan, dan lainlain), dan yang ketiga, pada hubungan antar kalimat (hubungan logis antar proposisi) yang biasa terdapat dalam wacana. Miller ${ }^{11}$ mengusulkan tiga tindak bahasa meliputi (1) tindak proposisi, (2) tindak ilokusioner, (3) tindak acuan konteks.

\section{B. Komponen Semantik}

Komponen semantik terdapat tahapan sebagai turunan dari konteks menuju fungsi tindak tutur dan dari fungsi menuju tahapan-tahapan yang ada di komponen semantik. Tahapan yang ada dalam komponen semantik dipengaruhi konteks dan fungsi tindak tutur (yang terdapat di dalam komponen pragmatik). Ini berarti pragmatik dan semantik mempunyai kaitan yang sangat erat.

Tahapan yang diteruskan dari komponen pragmatik tersebut pertama kali merupakan (1) pengacuan kepada unsur-unsur alat komunikasi, (2) didapatkan makna, lalu dilanjutkan dengan (3) strategi, yaitu pemilihan unsur alat komunikasi, sehingga pada tingkat inskripsi, tuturan merupakan kesatuan dari unsur-unsur alat komunikasi, yaitu unsur tindak tutur dan modalitas + proposisi, di mana unsur-unsur tersebut satu dengan yang lainnya mempunyai

${ }^{10}$ M.A.K. Halliday, "Language Structure and Language Function" di dalam J. Lyons (ed.), New Horizon in Linguistics, (Harmondworth: Pinguin 1970).

${ }^{11}$ Max Miller, The Logic of Language in Early Childhood, (New York: Springer, 1979). 
deskriptif dengan menggunakan studi kasus untuk mengumpulkan data. Subjek penelitian adalah Dosen Pembimbing Skripsi di Program Studi Manajemen Pendidikan Islam STAIN Sultan Abdurrahman Kepulauan Riau yang sedang melakukan proses pembimbingan skripsi dan Mahasiswa Program Studi Manajemen Pendidikan Islam STAIN Sultan Abdurrahman Kepulauan Riau yang sedang melakukan proses bimbingan skripsi.

Populasi adalah keseluruhan objek penelitian yang terdiri dari manusia, benda, tumbuh-tumbuhan dan peristiwa sebagai sumber data yang mempunyai karakteristik tertentu dalam sebuah penelitian. ${ }^{14}$ Suharsimi Arikunto mengatakan bahwa populasi adalah keseluruhan subyek penelitian. Apabila seseorang ingin meneliti semua elemen yang ada dalam wilayah penelitian, maka penelitiannya merupakan penelitian populasi. ${ }^{15}$ Jumlah populasi yang merupakan responden dalam penelitian ini terdiri dari 19 orang Mahasiswa Manajemen Pendidikan Islam yang sedang melakukan proses bimbingan Skripsi dan 12 orang Dosen Pembimbing Skripsi.

Pengumpulan data dalam penelitian ini menggunakan teknik perekaman video atau audio ketika proses bimbingan skripsi berlangsung. Selain itu juga menggunakan pedoman observasi dan pedoman wawancara (interview guide). Observasi dibatasi pada indikator komponen pragmatik sesuai konteks situasi dan kondisi bimbingan skripsi. Wawancara dibatasi dengan pertanyaan yang berkaitan dengan indikator model gramatika komunikatif yang efektif, yaitu komponen pragmatik,

\footnotetext{
${ }^{14}$ Herman Resito, Pengantar Metodologi Penelitian (Jakarta: Gramedia Pustaka Utama, 1992), h. 49

${ }^{15}$ Suharsimi Arikunto, Prosedur Penelitian Suatu Pendekatan Dan Praktek, (Jakarta: PT. Rineka Cipta, 2002), h. 130
}

komponen sintaksis dan komponen semantik yang ditujukan pada dosen pembimbing skripsi dan mahasiswa yang sedang dibimbingnya.

Metode pengumpulan data adalah informasi yang dapat diperoleh melalui pengukuran-pengukuran tertentu, untuk digunakan sebagai landasan dalam menyusun argumentasi logis menjadi fakta. ${ }^{16}$ Teknik pengumpulan data dapat juga diartikan suatu cara yang dilakukan oleh peneliti untuk mendapatkan data yang relevan.

Data yang sudah dikumpulkan kemudian dianalisis. Penganalisisan sebuah tuturan selalu berpijak pada konteks situasi tutur ketika proses bimbingan skripsi berlangsung, bagian apa saja yang masuk dalam komponen pragmatik tanpa mengabaikan komponen sintaksis, dan komponen semantik, sekurang-kurangnya melibatkan konteks wacana (kalau tidak ditemukan konteks budaya dan atau konteks langsung pada data yang telah dikumpulkan.

Setelah data terkumpul melalui teknik pengumpulan data, selanjutnya adalah menganalisis data tersebut, dalam memberikan interpretasi data yang diperoleh peneliti menggunakan metode deskriptif. Teknik analisis deskriptif yaitu suatu teknik penelitian yang meliputi proses pengumpulan data yang sudah terkumpul dan tersusun tersebut dianalisis sehingga diperoleh penelitian data yang jelas. ${ }^{17}$

Analisa terhadap data kualitatif dalam penelitian ini terdiri dari tiga alur kegiatan yang terjadi secara bersamaan yaitu reduksi data, penyajian data dan penarikan kesimpulan/verifikasi.

\section{HASIL DAN DISKUSI}

\footnotetext{
${ }^{16}$ Abdurrahmat Fathoni, Metodologi Penelitian \& Teknik Penyususnan Skripsi. (Jakarta: Rieneka Cipta, 2006), h.104

17 Lexy J. Moleong, Metodologi penelitian, h. 217
} 
Konteks tidak dapat lepas dari bentuk bahasa yang ada dalam mengkaji gramatika suatu bahasa. Hubungan timbal balik antara konteks dan makna, dan antar makna dan bentuk tuturan tidak dapat dihindarkan dari kajian gramatika bahasa. Dengan kata lain pragmatik, semantik dan sintaksis tak dapat dipisahkan satu sama lain. ${ }^{18}$

\section{Komponen Pragmatik:}

Data 1

A : Apa judul Skripsi Anda?

B : Profesionalisme Pengelolaan Siswa Kelas Akhir IX (Sembilan) di SMP IT Ulil Albab Batam.

A: Di skripsi yang Anda buat Anda belum menceritakan masalah yang yang berkaitan dengan judul Anda. Munculkan masalah dulu! Pertemuan berikutnya Anda harus sudah mencantumkan masalah di latar belakang.

B: Baik pak

Konteks:

Memunculkan masalah di tempat penelitian yang sesuai dengan judul.

(2 kali pertemuan masih mengenai memunculkan masalah).

Komponen Semantik: makna kurang komunikatif terlihat pada rincian konteks Memunculkan masalah di tempat penelitian yang sesuai dengan judul, yang seharusnya dalam konteks semantik atau konteks pemaknaan, bukan memunculkan masalah tetapi masalah memang sudah ada di tempat penelitian. Kajian dari komponen semantik atau pemaknaan menjadi rancu, apakah munculkan masalah di skripsi atau memunculkan masalah di tempat penelitian.

Komponen Sintaksis: Memunculkan masalah di tempat penelitian yang sesuai dengan judul. Uraian konteks kalimat sebaiknya diperbaiki agar lebih komunikatif.

\section{Komponen Pragmatik}

Data 17

A : Assalamu'alaikum, pak. Selamat malam.

B :WaalaikumsalamWr. Wb. Silahkan masuk.

A: Ini pak skripsi saya.

B: Kalau bapak perhatikan skripsi ini perlu perubahan judul sedikit, dari sistem pengelolaan menjadi perencanaan RAPBS di MTs Darul Falah ditinjau dari Manajemen Keuangan Sekolah

A: Begitu ya pak.

B: Terus perubahan dalam latar belakang masalah

A: Ia pak bagian lain gimana pak, kira-kira sudah benar pak.

B: masih banyak yang harus direvisi, sekarang fokuskan di Indikator masukkan beberapa item, sesuai dengan teori manajemen keuangan

A: Syukron pak, Insya Allah akan saya perbaiki. Pamit ya pak. Assalamualaikum Wr. Wb

B: Waalaikumsalam.

Komponen Semantik: sudah komunikatif terlihat dari tindak tutur komunikatif timbal balik antara dosen pembimbing dan mahasiswa.

Komponen Sintaksis: beberapa tuturan kalimat sudah komunikatif terlihat pada tuturan berikut:

B: Kalau bapak perhatikan skripsi ini perlu perubahan judul sedikit, dari sistem pengelolaan menjadi perencanaan RAPBS di MTs Darul Falah ditinjau dari Manajemen Keuangan Sekolah

A: Begitu ya pak.

B: Terus perubahan dalam latar belakang masalah

A: Ia pak bagian lain gimana pak, kira-kira sudah benar pak.

\footnotetext{
${ }^{18}$ Anas Yasin, Tindak Tutur, h.58.
} 
B: masih banyak yang harus direvisi, sekarang fokuskan di Indikator masukkan beberapa item, sesuai dengan teori manajemen keuangan.

Namun ada yang perlu ditambahkan pada tuturan kira-kira sudah benar pak ini apakah bentuk kalimat pernyataan atau kalimat pertanyaan dari kajian komponen sintaksis atau kajian komponen kalimat. Hal ini juga berpengaruh pada sistem komponen semantik atau komponen makna yang terbentuk dari tuturan kira-kira sudah benar pak., bermakna ganda, bisa saja bagian lain sudah benar atau belum benar. Oleh karena itu perlu ditambahkan salah satu unsur penanda kalimat tanya $5 \mathrm{~W}+1 \mathrm{H}$, yaitu unsur apa, menjadi apa kira-kira sudah benar pak?

\section{Data 19}

A : Assalamualaikum,wrwb. Bagaimana kabarnya bapak? Semoga sehat walafiat. Amien.

B : Waalaikumsalam, Wr Wb. Alhamdulillah kami sekeluarga sehat. Amien Bagaimana dengan penulisan skripsinya, sudah sampai di mana?

A: Alhamdulillah bapak, Insya Allah masih perjalanan semoga tak ada kendala. Beranjak ke BAB IV, hampir selesai

B : Alhamdulillah, semoga cepat selesai, bagaimana dengan BAB I nya,

Komponen Semantik: Insya Allah masib perjalanan dikaitkan dengan pertanyaan bagaimana dengan penulisan skripsinya kurang tepat digunakan. Sebaiknya kata masih perjalanan_diganti Insya Allah masih dalam proses penyusunan.

Sifat konteks yang utama adalah dinamis, berubah, karena itu konteks merupakan proses peristiwa yang mempunyai batasan persyaratan yang harus dipenuhi untuk kualifikasi tahap awal atau tahap akhir proses peristiwa tersebut. Kemungkinan konteks tidak terbatas, namun seseorang dapat mengacu pada konteks-konteks tertentu yang disebut konteks aktual yang dibatasi oleh jangka waktu dan tempat di mana kegiatan yang sama dari pembicara dan pendengar dilakukan, dan yang memenuhi ciri-ciri di sini dan saat ini secara logis, fisik dan kognitif. Konteks aktual mempunyai satuan alternatif. Beberapa diantaranya normal dan memenuhi postulat dasar proses-proses komunikasi ${ }^{19}$ Berikut ini pada Data 19 dan Data 31 terdapat tuturan konteks aktual menggunakan ciri ke sana dan dari sana menunjukkan tempat di mana kegiatan yang sama dari pembicara dan pendengar dilakukan:

\section{Data 19}

A : Assalamualaikum bapak kami sudah di tempat.

B : Iya, tunggu aja bapak mau ke sana, bagaimana yang kemarin sudah siap. Alhamdulillah.

Konteks:

BAB II penelitian harus relevan (Contoh dari skripsi yang sudah ada) diperbaiki lagi, ditambahkan tempat penelitiannya di mana? Sama variabel sub variabel dan indikatornya untuk membuat pengukuran dalam penelitian.

A : Insya Allah bapak.

B : Semoga cepat selesai.

\section{Data 31}

C: Loh kok di kartu bimbingan skripsi ini nama dan gelar saya salah semua? Wah enaklah saya dapat gelar baru S.HI..... (sambil tertawa).

A : Maaf bu saya gak tau, dari sananya saya dapatnya begitu adanya (senyum). Terus yang benar nama lengkap dan gelar ibu apa?

C : ini nama dan gelar saya (sambil menulis di kartu bimbingan skripsi). *SULISTIYOWATI GANDARIYAH AFKARI, M.Ed*

Oke ya kita lanjut ke bimbingan.

\footnotetext{
${ }^{19}$ Ibid. h.50.
} 


\section{Komponen Pragmatik \\ Data 10}

A : Assalamu'alaikum, pak. Selamat siang pak.

B : Waalaikumsalam Wr. Wb.

A: Bimbingan pak ini skripsi saya pak.

B: Coba kamu cari banyak di internet teori bagaimana suatu laporan itu dianggap layak sehingga kamu bisa memahami dan menguasai apa saja bentuk laporan yang layak tersebut.

\section{Komponen Sintaksis}

B: Coba kamu cari banyak di internet teori bagaimana suatu laporan itu dianggap layak sehingga kamu bisa memahami dan menguasai apa saja bentuk laporan yang layak tersebut.

Tuturan yang mengandung makna pragmatik imperatif suruhan pada komponen sintaksis, terdapat pada kata Coba.

Moeliono menjelaskan dalam $\operatorname{Nadar}^{20}$ bahwa kalimat perintah atau kalimat imperatif adalah kalimat yang maknanya memberikan perintah untuk melakukan sesuatu. Kalimat yang dapat memiliki bentuk perintah pada umumnya adalah kalimat tak transitif atau transitif (baik aktif maupun pasif). Contoh-contoh yang diberikan antara lain: "Berliburlah ke tempat nenekmu" (Kalimat perintah tak transitif); Belikanlah adikmu sepatu baru" (Kalimat perintah transitif aktif); "Dijual saja mobil tua seperti itu" (Kalimat perintah bentuk pasif); "Coba panggillah Kepala Bagian Umum" (Penghalusan Kalimat Perintah); "Jangan pergi sekarang" (Bentuk ingkar pada kalimat perintah).

\section{Komponen Sintaksis dan Pragmatik Data 40}

A : Yogi tolong diperbaiki sistematika penulisannya lalu nanti jika sudah

20 FX. Nadar, Pragmatik dan Penelitian Pragmatik, h.73. siap kamu kembali ke rumah bapak lagi kita lanjutkan bab 4

B : siap pak said saya usahakan secepatnya saya selesaikan pak.

Tuturan yang mengandung makna pragmatik imperatif permintaan misalnya ditandai dengan menggunakan kata tolong ${ }^{21}$ pada contoh kalimat " Tolong matikan lampunya,"

Data 40 dan Data 12 juga mengandung makna pragmatik imperatif permintaan seperti pada tuturan:

A : Yogi tolong diperbaiki sistematika penulisannya lalu nanti jika sudah siap kamu kembali ke rumah bapak lagi kita lanjutkan bab 4.

\section{Data 12}

A : Assalamu'alaikum, pak.

B :WaalaikumsalamWr. Wb.

A: Ini pak sudah saya lengkapkan sampai Bab V dan kesimpulannya.

B: Bagus, tolong perhatikan dan fahami rumusan masalahnya dan tolong hasil penelitiannya ditambah kok cuma segini?

A: Baik pak Insha Allah akan saya tambah kalimatnya

B: dan tolong dirubah jangan memakai kata jika pada awal kalimatnya kurang pas, segera dirubah agar kalimatnya lebih baik lagi

Selain kata tolong pada Data 12 juga terdapat tuturan yang mengandung makna pragmatik imperatif larangan ditandai dengan penggunaan kata Jangan pada tuturan kalimat ".....jangan memakai kata jika pada awal kalimatnya kurang pas, segera dirubah agar kalimatnya lebih baik lagi."

\section{KESIMPULAN}

Konteks tidak dapat lepas dari bentuk bahasa yang ada dalam mengkaji gramatika suatu bahasa. Hubungan timbal balik antara konteks dan makna, dan antar makna dan bentuk tuturan tidak dapat dihindarkan dari kajian gramatika 
bahasa. Dengan kata lain pragmatik, semantik dan sintaksis tak dapat dipisahkan satu sama lain.

Sifat konteks yang utama adalah dinamis, berubah, karena itu konteks merupakan proses peristiwa yang mempunyai batasan persyaratan yang harus dipenuhi untuk kualifikasi tahap awal atau tahap akhir proses peristiwa tersebut. Kemungkinan konteks tidak terbatas, namun seseorang dapat mengacu pada konteks-konteks tertentu yang disebut konteks aktual yang dibatasi oleh jangka waktu dan tempat di mana kegiatan yang sama dari pembicara dan pendengar dilakukan, dan yang memenuhi ciri-ciri di sini dan saat ini secara logis, fisik dan kognitif. Konteks aktual mempunyai satuan alternatif. Beberapa diantaranya normal dan memenuhi postulat dasar proses-proses komunikasi. Pada Komponen Pragmatik Data 19 dan Data 31 terdapat tuturan konteks aktual menggunakan ciri ke sana dan dari sana menunjukkan tempat di mana kegiatan yang sama dari pembicara dan pendengar dilakukan:

Beberapa tuturan dalam proses bimbingan skripsi antara mahasiswa dengan dosen pembimbing telah ditemukan ada yang sudah komunikatif dan ada yang belum komunikatif pada komponen pragmatik, komponen semantik dan komponen sintaksis. Beberapa tuturan kalimat perintah dan kalimat permintaan pada komponen sintaksis telah memenuhi aneka kalimat bahasa Indonesia dari sudut pandang komunikatifnya.

Diharapkan, hasil kajian model gramatika komunikatif diharapkan dapat memberikan kontribusi positif terhadap bimbingan skripsi mahasiswa Program Studi Manajemen Pendidikan Islam STAIN Sultan Abdurrahman Kepulauan Riau.[]

\section{DAFTAR PUSTAKA}

Arikunto, Suharsimi, Prosedur Penelitian Suatu Pendekatan Dan Praktek, Jakarta: PT. Rineka Cipta, 2002

Brown, Gillian dan George Yule. 1985. Discourse Analysis. London: Cambridge University Press.

Fathoni, Abdurrahmat, Metodologi Penelitian \& Teknik Penyususnan Skripsi. (Jakarta: Rieneka Cipta, 2006

Freedle, Roy. 1979. "Sociolinguistic Approach to Dialogue with Suggested Aplications to Cognitive Science", di dalam Roy Freedle (ed.), New Directions in Discourse Processesing, Vol. II, Advances in Discourse Processes. Norwood: Ablex Publishing Corporation.

Halliday, M.A.K. 1970. "Language Structure and Language Function" di dalam J. Lyons (ed.), New Horizon in Linguistics. Harmondworth: Pinguin.

Leech, Geoffrey, Principles of Pragmatics. London: Longman Group, 1983.

Miller, Max, The Logic of Language in Early Childhood, New York: Springer, 1979.

Moates, Danny R. dan Gary M. Schumacher, Cognitive Psychology, Belmont: Wodsworth Publishing Company, 1980.

Moleong, Lexy J, Metodologi Penelitian Kualitatif, Bandung: PT. Remaja Rosdakarya, 1993

Nadar, F.X., Pragmatik dan Penelitian Pragmatik, Yogyakarta: Graha Ilmu, 2009.

Resito, Herman, Pengantar Metodologi Penelitian Jakarta: Gramedia Pustaka Utama, 1992

Wardhaugh, Ronald, The Context of Language, Rowley: Newbury House Publishers, 1976.

Werth, Paul, Focus, Coherence, and Emphasis. London: Croom Helm, 1984. 
Yasin, Anas, Tindak Tutur: Sebuah Model

Gramatika Komunikatif, Padang:

Sukabina Offset, 2008.

186 Perada: Jurnal Studi Islam Kawasan Melayu, Vol. 2, No. 2, Desember 2019

http://ejournal.stainkepri.ac.id/index.php/perada 